with Dr. Dwerryhouse, but nothing comparable with the scale on which the gravel and concrete hunters work to-day. The dimensions of the exposure and the rapid rate of working provide an excellent opportunity for studying structures only rarely to be seen in this country, and make it imperative that some competent glaciologist should watch the progress of the work and record the structures revealed in the developing face.

DEPARTMENT OF GEOGRAPHY,

A. Austin Miller.

THE UNIVERSITY,

READING.

6th September, 1948.

\title{
BATHONELLA AND VIVIPARUS
}

SiR,-Dr. Cox has put forward arguments in favour of regarding Valvata comes from the Viviparus Marl of Oxfordshire as a marine species of another genus. Dr. Yen contends that the Viviparus itself (V. langtonensis) is a marine species of his genus Bathonella. It therefore seems desirable to place on record the occurrence of two forms from the Viviparus Marl that are more certainly of freshwater origin. From samples collected at both Castle Barn and Sharp's Hill, the Marl has yielded an undescribed species of the ostracod genus Metacypris, and the gyrogonites of a Charophyte. Recent Charophyta are exclusively freshwater. Recent Metacypris inhabit the almost freshwater broads of the Fenland. Both Charophytes and Metacypris are abundant associates of Viviparus and Valvata in the Cherty Freshwater Beds of the Middle Purbeck of Dorset. At the same time, it must be admitted that I have also found gyrogonites (but not Metacypris) in certain members of the underlying Sharp's Hill Beds usually regarded as marine.

DePartment of Geology,

P. C. Sylvester Bradley.

ST. GeORGE's SQUARE, SHEFFIELD, 1.

2nd October, 1948.

\section{BATHONIAN AMMONITES}

SIR,-I am anxious to examine for a monograph in preparation all ammonites from the Fuller's Earth, Fuller's Earth Rock, Stonesfield or Cotswold Slates, Great Oolite, Forest Marble, and Cornbrash. If any collector or curator will send me material on loan it will be gratefully acknowledged and carefully returned as soon as examined. Ammonites are so rare in some of these formations that even a fragment may be something new and stratigraphically important if accurately localized.

\section{SEDGWICK MUSEUM,}

W. J. ARKeLL.

CAMBRIDGE.

11th October, 1948.

\section{EAST ANGLIAN DRIFTS}

SIR,-Mr. Baden Powell's paper on East Anglian drifts ${ }^{1}$ adds greatly to our knowledge : his data, which must have cost much time and labour to amass, will, I feel sure, be of permanent value. Nor would I quarrel with his sequence, if the Hoxne beds could be placed on top of all, not in the middle. But though in accord with current practice, the four glaciations claimed, with their appropriate intervals, can, and should, be challenged.

1 D. F. W. Baden Powell. The Chalky Boulder Clays of Norfolk and Suffolk. Geol. Mag., Oct., 1948, pp. 279-296. 